\title{
10 \\ Bringing Australia and the EU Closer: Is an FTA a Solution?
}

\author{
Paul Gretton
}

\section{Introduction}

At a time when the prospects for finalising the Doha Round of trade negotiations is bleak, it is timely to consider what kind of trade policy agenda governments should be pursuing. One possible approach is the continuation of strategies based on the negotiation of preferences through bilateral and regional deals. Another approach would be to refocus attention on trade liberalisation based on the most favoured nation (MFN) and national treatment principles of the international trading system, supported by domestic reform. Such an approach would be directed at enabling economies to adapt to the increasingly integrated global trading environment and to reach their productive potential. Bringing the like-minded trade-oriented economies of the European Union (EU) and Australia together provides the opportunity to eliminate remaining impediments to trade and investment between the regions according to MFN/national treatment principles. It also affords an opportunity to consider mutually beneficial behind-the-border reforms.

Industry consultations towards securing improved economic cooperation will indicate some business priorities_ones that are properly focused on overcoming sticking points in international commerce and providing market access to business. 
The perspectives on what a trade agenda and trading environment may deliver, though, will vary. Individual companies could ask: 'What is in it for my business?' The wider community should ask: 'Will an agreement provide community-wide benefits?' The answer to these questions is not necessarily the same for all. But the subtext for all scenarios is to consider: 'Are benefits the greatest available?' 'Will an arrangement impede future commercial and policy options?'

This leads to the need to consider appropriate architectures and trade liberalisation strategies. It appears to this writer that there are no 'free trade' agreements. Yes, there are binding agreements between countries and groups of countries that exchange preferences, and the formation of such arrangements has clearly gained momentum with the stalling of the Doha Round. But such arrangements:

- encourage holding back worthwhile domestic reforms to maintain 'negotiating coin' for the next negotiation;

- involve diversion of highly skilled resources in tit-for-tat negotiations;

- lead to new regulations in the form of rules of origin and preferences impeding efficient decision-making in merchandise and services trade, and investment; and

- favour businesses directly advantaged by negotiated preferences.

This is at the cost of other domestic businesses that may be more productive and internationally competitive, and at the expense of those countries and their businesses that are excluded from the particular agreement in question.

There is also an emerging tendency to include in preferential trade agreements provisions that depart from the national treatment principle to afford procedural rights to foreign companies not available to local enterprises through investor-state dispute settlement (ISDS) or impose more stringent intellectual property (IP) provisions that benefit IP holders while raising the cost of IP use to the rest of the community.

In short, bringing the Australian and $\mathrm{EU}$ economies closer together in a mutually beneficial way depends on ongoing domestic economic reforms that are genuinely trade liberalising. What could the elements be? 


\section{Trade and competitiveness - where do impediments bite?}

While the trade strategies will have a major impact on potential benefits and what is realisable, the footprint of activities brought within the negotiations will also be important. One broad way of looking at this issue is to look at what is traded across borders and what is 'behind the border' or, put another way, the value added in trade.

Global trade statistics show that trade relations between economies are dominated by merchandise trade, mainly in manufactures (Figure 1). Further analysis now becoming available based on input-output modelling shows that behind-the-border services are key to realising the potential of economies. Assessments of how the productivity of domestic service provision can be improved would be a good starting point for improving the overall competitiveness of an economy. However, trade barriers in the form of tariffs, rules of origin and non-tariff barriers (NTBs) will not only raise the cost of imports to domestic industry and consumers, but also impede realisation of the productive potential of services.

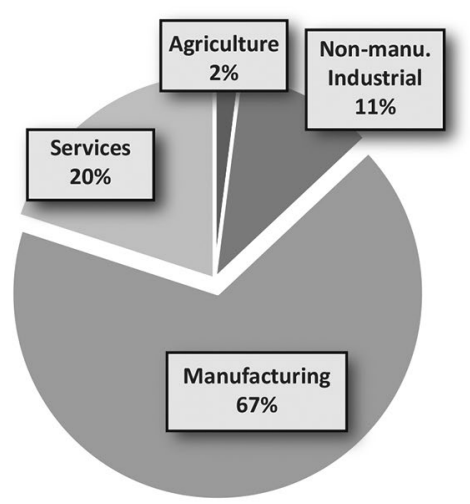

Global exports industry of origin ${ }^{\mathrm{a}} 2008$

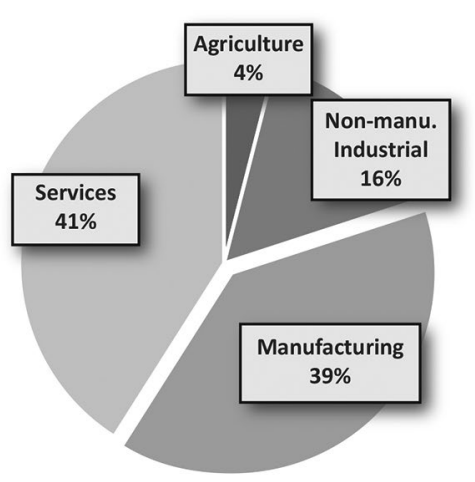

Value added in global exports ${ }^{\mathrm{a}} 2008$

Figure 1. While trade relations are dominated by merchandise trade, behind-the-border services productivity is key to competitiveness

a) Agriculture includes forestry, hunting, and fishing. Non-manufacturing industrial production includes mining and quarrying, electricity/gas/water supply, and construction. Manufacturing is the remainder of industrial production

Source: Johnson 2014. 
World trade and production are also increasingly structured around 'global value chains'. A value chain identifies the full range of activities that firms undertake to bring a product or a service from its conception to its end use.

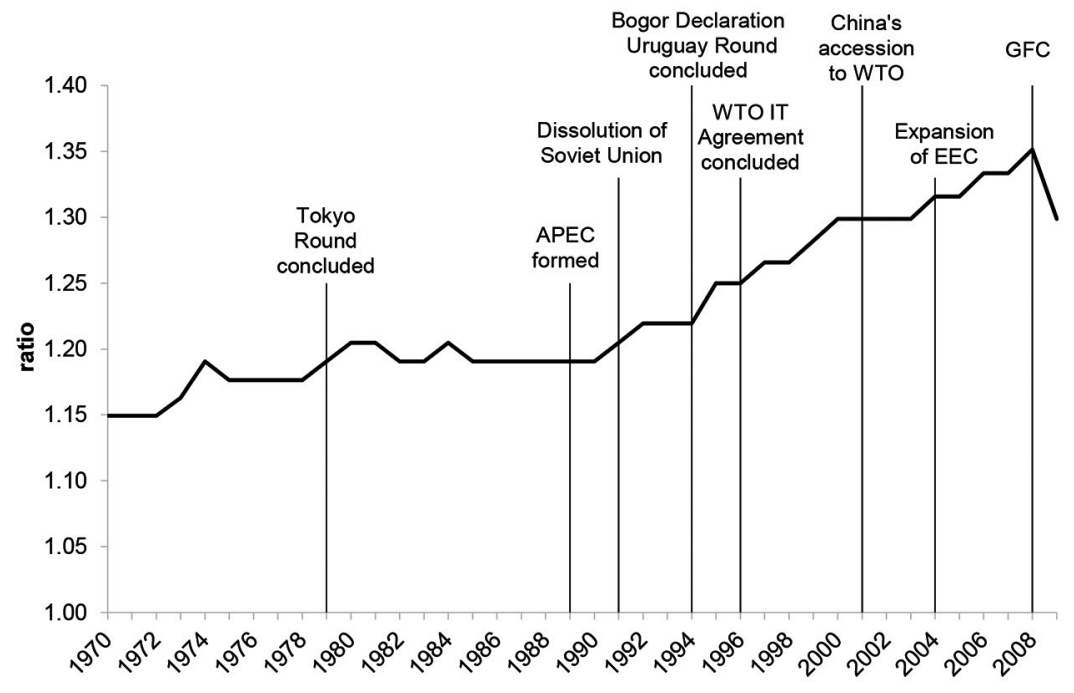

Figure 2. The ratio of the global gross value of exports to the value added in exports has increased, 1970 to $2009^{a}$

APEC, Asia-Pacific Economic Cooperation; EEC, European Economic Community; GFC, global financial crisis; IT, Information Technology; WTO, World Trade Organization

a) The original estimates of Johnson and Noguera were expressed in terms of value added exports to gross exports (the VAX ratio), the inverse of the ratio reported in this figure.

Sources: Based on Johnson \& Noguera 2012; Productivity Commission 2015a.

As production processes have increasingly been dispersed across countries to take advantage of lower-cost production opportunities and the level of inter-industry trade has increased, the gross value of exports to the value added generated has increased. Over the period 1970 to around 2009, available estimates indicate exports per unit of value added increased from 1.15 to 1.33 - that is, by around 15 per cent (Figure 2). ${ }^{1}$ Most of this increase occurred after 1990, coinciding with major trade liberalisations - including those associated with the formation of the

1 'Gross exports per unit of value added' is the inverse of what is commonly known in the empirical trade literature as the ratio of 'value added exports' (VAX) to gross exports (Johnson \& Noguera 2012). Aggregate value added exports is less than gross exports because of the existence of intermediate stages of production within and across countries. 
Asia-Pacific Economic Cooperation (APEC) in 1989 and the Bogor Declaration of 1994, China's accession to the World Trade Organization (WTO) in 2001, the expansion of the EU to include former Soviet bloc economies, and the emergence and uptake of advanced information and communication technologies. With the contraction of global trade associated with the 2008 global financial crisis, global exports per unit of value added, however, declined.

The increase in the ratio of gross exports to value added between 1970 and 2009, and particularly after 1990, predominantly reflects structural changes within the global manufacturing sector (Figure 3). In particular, while exports of final manufactures grew, the number of stages (or slicing up) of the stock of final manufactures increased faster. As a result, the value of exports of manufactures relative to the value added embodied in those exports has risen over 30 per cent-mainly since 1990. In contrast, exports of agriculture and services per unit of value added has slightly declined-as the value of exports of agriculture and services have grown slower than the use of those products as inputs into the increasingly fragmented manufacturing sector and into final consumption.

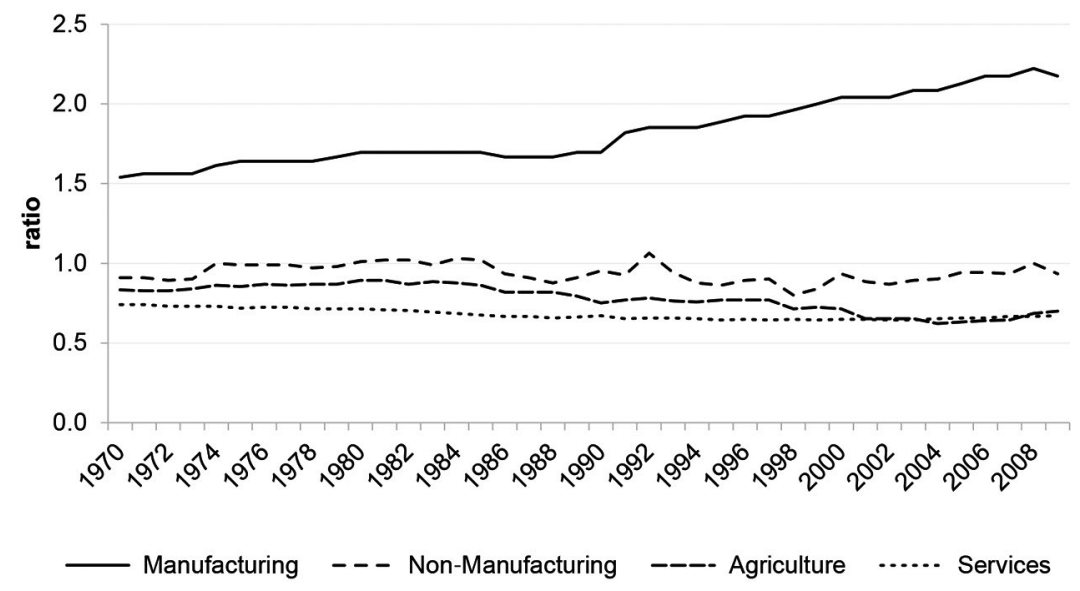

Figure 3. Changes in global exports per unit value added by sector, 1970 to $2009^{a}$

a) Non-manufacturing includes oil and gas, iron ore and other mining.

Source: Based on Johnson \& Noguera 2012. 


\section{A key impediment to liberalising merchandise trade-remaining tariffs and rules of origin}

Average tariffs are low in EU economies and Australia for primary products and manufactures, both in absolute terms and relative to other economies (Figure 4, left-hand panel) while average tariffs at a global level have been on the decline (Figure 4, right-hand panel).

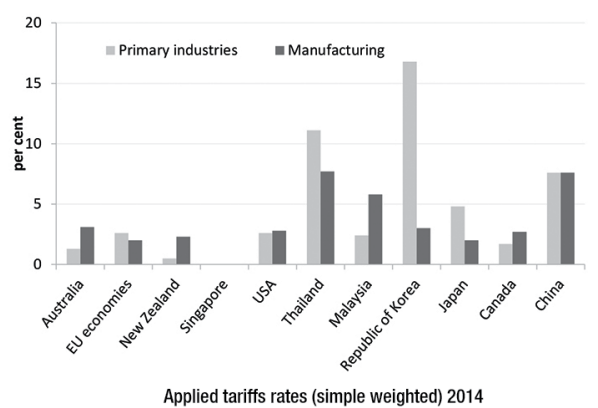

Figure 4. Customs tariffs remain

Source: World Bank 2016b.

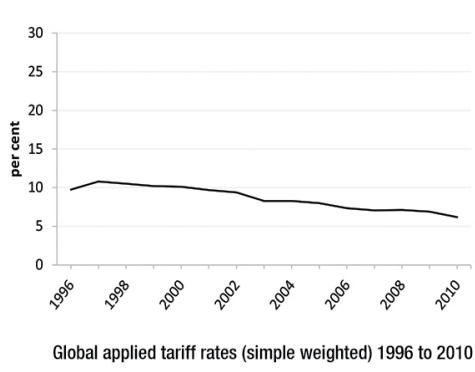

Despite the fact that import tariffs are at historically low levels and suggestions that tariff protection is less important than was historically the case, the formation of modern preferential bilateral and regional trade agreements has been accompanied by the negotiation of complex productspecific rules of origin to establish eligibility for trade preferences under an agreement. The requirement for product and agreement-specific origin rules suggests that remaining tariffs do bite and that the tariff preference is material. Tariff preferences extend tariff assistance to qualifying firms in partner economies otherwise reserved for local firms (Productivity Commission 2004a). Although difficult to quantify, trade preferences and origin rules have a number of effects that impede economic efficiency and lower productivity. They can:

- divert trade in final goods from lower-cost suppliers of competing products;

- lead some firms to adopt a more costly input mix and higher cost structure in order to obtain preferential access for finished products; and

- induce changes in the location of investment between members of a preferential agreement and between members and non-members (Productivity Commission 2004b). 
They also add to the risk of doing business arising from the potential for delay in documentation and clearance and failure to meet origin requirements.

With the increasing number of preferential trade agreements, there are now many countries that have separate, differently specified rules of origin with different trading partners. This has led to a complex system of 'criss-crossing' trade preferences where products entering a particular country enjoy access on widely varying terms depending on their origin, leading to a 'spaghetti/noodle bowl' across agreements or 'hub and spoke' effect between one (large) economy and trading partners linked to it by bilateral agreements.

Preferential trade agreements contain a range of approaches for conferring origin that businesses must consider when sourcing inputs to attain concessional tariff rates for merchandise trade commonly centred around change of tariff classification, specified process or regional value content tests. Some products, typically agricultural or mining, can also be prescribed as being 'wholly obtained' or 'produced entirely locally'.

These approaches (or tests) are variously applied individually or in combination to determine origin. In the case of agreements entered into by Australia to date, the application of the approaches varies between products within agreements and, for individual products, between agreements-for example, from a single three-tiered rule in the agreement with Singapore based on a regional value content approach to more than 5,200 individual rules in the agreement with Korea based on productspecific rules for each Harmonized System (HS) item (Table 1).

Table 1. Count of listed rules of origin by trade agreement

\begin{tabular}{|l|l|}
\hline \multicolumn{2}{|l|}{ Number of rules listed in agreements } \\
\hline New Zealand & 2813 \\
\hline Singapore & 1 \\
\hline Thailand & 2907 \\
\hline USA & 980 \\
\hline Chile & 2803 \\
\hline ASEAN & 3102 \\
\hline Malaysia & 2677 \\
\hline Korea & 5205 \\
\hline Japan & 2171 \\
\hline China & 1784 \\
\hline
\end{tabular}

Source: Productivity Commission 2015b; Author estimates. 
In addition to differences in the number of origin rules listed in schedules, there is also a diversity of approaches used for conferring origin. The most common rule is the change in tariff classification (CTC) test, but there is considerable variation in how CTC rules are combined with other rules (Figure 5, left-hand panel) and how they are applied across agreements (Figure 5, right-hand panel).

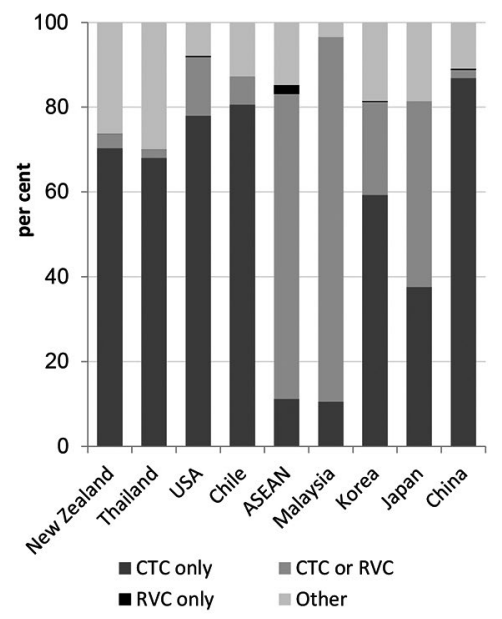

Rule for determining origin Per cent of specified rules ${ }^{c}$

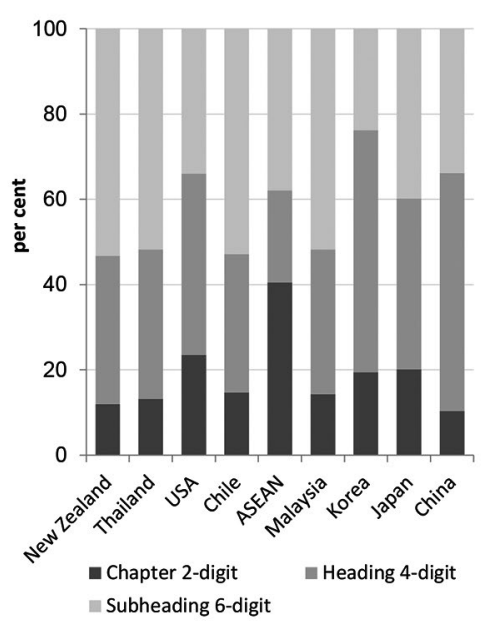

Application of CTC method ${ }^{d}$ Per cent of specified CTC rules ${ }^{c}$

Figure 5. Methods used to determine origin of merchandise trade in Australian preferential trade agreements $\mathrm{s}^{\mathrm{a}, \mathrm{b}, \mathrm{c}, \mathrm{d}}$

a) CTC refers to a change in tariff classification test. RVC refers to a regional or qualifying value content rule. 'Other' includes combined CTC and RVC rules, CTC rules with exceptions and specified process tests requiring particular production methods to be applied; b) The agreement with Singapore is not included as it applies a single three-tiered test of origin; c) Individual rules can be expressed at the 4-digit heading level, 6-digit subheading level or groupings of tariff line items; d) When the Australia-New Zealand Closer Economic Relations (CER) agreement entered into force in 1983, an RVC rule with a simple technical test was the main rule applied. The rules reported replaced that rule and have been in force since 1 January 2007.

Source: Productivity Commission 2015b; Author estimates.

The different rules and rule structures across agreements mean that a firm trading with multiple countries faces greater complexity and compliance costs through the need to interpret, and comply with, different rules of origin. Although difficult to quantify, it has been estimated that the economic cost associated with these requirements could be as high as 25 per cent of the value of goods traded within the Association of Southeast Asian Nations (ASEAN) (APEC 2009, with reference to Manchin \& Pelkmans-Balaoing 2007). At this level, it would be more 
cost-effective to pay the tariff than seek the tariff concession for many products. In a recent assessment of the potential impacts of a trans-Pacific partnership by the World Bank, it was conjectured that rules of origin could lead to the replacement of 40 per cent of imported inputs, on average, with higher-cost inputs from agreement partners, as members diverted trade to take advantage of preferential tariffs under such an agreement (World Bank 2016a). These estimates illustrate the additional drag on productive efficiency introduced by preferential rules of origin.

In an attempt to move away from the ever-increasing complexity of rules of origin schedules in trade agreements, the Australian Productivity Commission has recommended on a number of occasions that, for locally sourced products, the rules be 'waived' between agreement partners when tariff rates in partner countries are similar or low-that is, when the risk of trans-shipment of non-partner exports is low (Productivity Commission 2004b, 2010). Given the low average tariff rates in both the EU and Australia and the distance separating the two areas (and attendant relatively high transport costs), this recommendation would have particular applicability in any agreement involving the exchange of tariff preferences between Australia and the EU.

\section{Rules of origin apply to services and investment too}

While the existence of rules of origin in goods trade is well known, their application (and associated consequences) in services trade and investment has received much less attention. Rather than defining the physical origin of the service or investment (the focus in goods trade), trade agreements have generally sought to delineate ownership or control and through this the origin of a service supplier or investor (Fink \& Nikomborirak 2007). The effect is to deny foreign (non-party) owned or controlled companies access to the provisions negotiated in trade agreements, although, as with rules of origin on merchandise trade, the expression of the rules differs between agreements.

For example, the Australia-United States of America (USA) bilateral agreement (in force since 2005) has adopted a services and investment origin rule denying benefits 'if the service supplier is an enterprise owned or controlled by persons of a non-Party or of the denying Party that has no substantial business activities in the territory of the other Party' (Articles 10.11 and 10.12). The Thailand-Australia Agreement (also in force since 2005) stipulates that a service supplier or investor must not be owned or controlled by persons of a non-party (Articles 804 and 905). 
The recent economic partnership agreement between Australia and Japan (in force since 2015) is more specific about the level of ownership, stipulating that an enterprise may be denied the benefits of the agreement if it is more than 50 per cent owned by a non-party or has a majority of its directors appointed by a non-party that has no substantial business activities in the area of the other party (Articles 9.14 and 9.17). On the other hand, the Australia-New Zealand Closer Economic Relations Agreement (ANZCERTA) (which entered into force in 1983) requires that a service or investment must not be indirectly provided by a person of neither member state (Articles 14 and 18).

This variability across agreements adds to the complexity and uncertainty facing foreign-owned or controlled service suppliers and investors with Australian operations seeking to utilise negotiated access commitments. The discretionary nature and vagueness of the services and investment rules of origin leave a number of questions concerning the actual or potential impact of the rules of origin on services trade and investment activity. For example:

'To what extent would the provisions chill (or influence) commercial activity that may otherwise have occurred?' and 'Under what circumstance would the partner government invoke the provisions and in such an event, how would terms such as 'enterprise', 'ownership and control' and 'substantial business undertaking' be interpreted in the context of the transaction in question?'

An issue is whether there is merit in seeking to confine liberalising measures for services and investment on the basis of ownership and control of the entities involved, or whether MFN/national treatment principles should be applied more widely.

\section{What about services?}

The coverage of modern bilateral and regional trade agreements is typically inclusive of chapters on services. This can be justified by the growth in services trade and the movement of natural persons for work and pleasure, and also on the grounds of the importance of services in supporting merchandise trade-the services value added component of trade. In looking at the services aspect of the implications of Australian bilateral and regional trade agreements up to 2010, the Productivity Commission found in a number of areas that the main impediments to 
effective competition by Australian service providers in partners' services markets appeared to be related to regulatory and institutional issues that lie outside the scope of agreements (Productivity Commission 2010a).

An earlier survey of offshore investment by 201 of Australia's largest firms indicated that the commercial imperative of getting closer to the customer is the main driver of offshore investment (Productivity Commission 2002). The survey also indicated that government influences were of secondary importance with tax being the most significant, ahead of labour market policies, foreign tariff arrangements, mergers and environmental regulation, and access to capital.

An issue for services trade liberalisation is whether in fact negotiated bilateral or regional preferential market access arrangements are the most effective way towards services trade liberalisation.

\section{Looking within for economic reform potential}

While remaining tariffs are still a defining feature of international merchandise trade and the trading relationship between economies given economies' resource endowments and proximity to global trading partners, the domestic institutional and regulatory environment will be a determining feature of economies' cost competitiveness and preparedness to trade in both goods and services. As with customs tariffs, governments can directly address possibilities to improve economic competitiveness and thereby raise economic output and incomes.

The importance of the domestic operating environment to the trading potential of agreement partners highlights the role of domestic reform in adding to commercial opportunities and contributing to the potential for trade and investment between economies. One approach is to identify and assess at the national level NTBs to international trade in goods and services, and investment to:

- identify regulatory and other impediments to efficient investment and the conduct of commerce, and reform potential;

- assess the potential direct impacts of possible reforms on economic variables such as productivity, costs and prices of local industry, participation of the workforce in employment, and the mobility of labour across industries and regions; and 
- assess the economy-wide impacts of possible changes and the timescale over which benefits may accrue and adjustment costs be incurred (Figure 6).

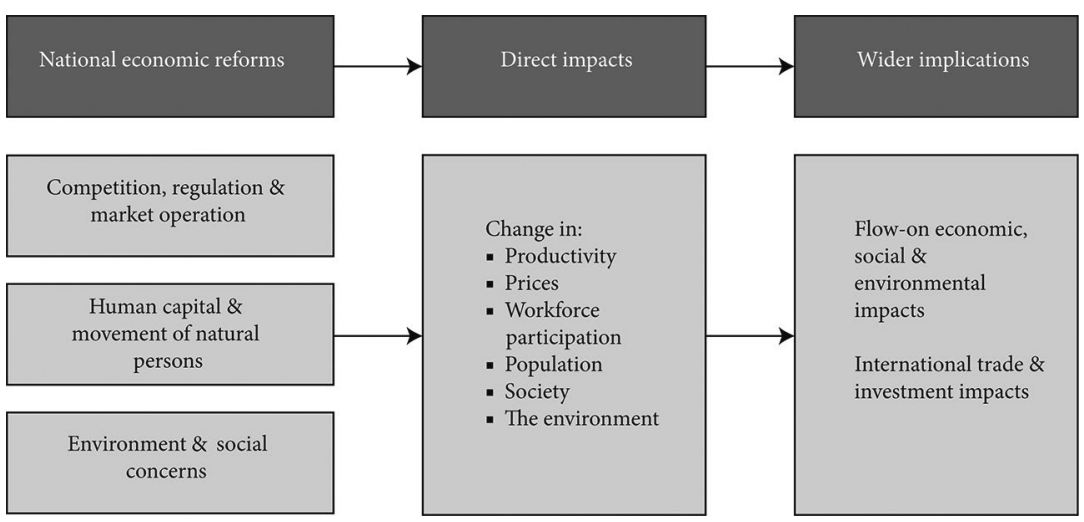

Figure 6. Identifying and assessing the impacts of reform potential Source: Based on Productivity Commission 2010b.

Such a framework has been developed and recently applied in the Australian context to assess the impacts of economic reforms in Australia (Productivity Commission 2010a, 2012). A similar framework was previously applied to assess the economic benefits of national competition policy reforms in Australia and an agenda for national reform (Productivity Commission 2005, 2006; Gretton 2013).

In relation to the 2012 study, the Productivity Commission was asked to assess the economic impacts of 17 business regulatory reforms underway. The reforms spanned a diverse range of activities and industries-some related to individual areas of domestic economic activity such as health workforce, wine labelling, construction and rail safety, while others operated more broadly, such as trade measurement, consumer law and occupational health and safety. A distinguishing feature of each of these reform areas required cooperation between Australian state and territory governments (which have jurisdiction over many of the matters considered) and the Australian Government, which has national responsibility for economic management.

Among other things, the policies include trade-related measures to improve the mobility of labour between jurisdictions with reference to the health workforce, and measures to facilitate trade with reference to trade measurement. In relation to the health workforce, until recently, 
registration of health professionals in Australia occurred on a state-bystate and profession-by-profession basis, with an array of government bodies and specific legislation. While accreditation was mainly undertaken on a national basis, there were still over 20 different bodies, with considerable differences in approaches across professions. Some were established in cooperation with peak professional associations, while others had explicit statutory functions or had responsibilities delegated from registering authorities. In order to improve the mobility of health labour across jurisdictions in Australia, the Commonwealth, state and territory governments implemented a new, nationally consistent system of registration and accreditation of health professionals intended to reduce the administrative burden, improve labour mobility, and increase the consistency and quality of training.

In consultation with regulators and industry participants, it was assessed that the changes would generate cost savings of around $\mathrm{A} \$ 160$ million per year, with some associated one-off adjusted costs (with around $\mathrm{A} \$ 20$ million being incurred by government and $\mathrm{A} \$ 24$ million by practitioners). Implementation was undertaken over a relatively short period and depended on broad-based and sustained commitment of both governments and the sector. It was conjectured that a more gradual approach to that adopted could have jeopardised the development.

The second area relates to trade measurement. While this reform was assessed as affording modest benefits in financial terms (a national cost reduction for business of around $\mathrm{A} \$ 5$ million per year), it draws attention to the myriad often small steps that can be taken by government to help facilitate trade. In this case, matters relating to the millions of consumer and business transactions in which the price paid is dependent on measures of quantity and/or quality (or product 'grade'). The use and verification of product measures in Australia is governed by trade measurement regulation. Despite the earlier changes, inconsistencies in approaches remained and a further change was made to centralise the approach within the Australian Government with the intention of achieving greater consistency and lowering administrative and business costs.

Across all areas, while any estimates of impacts are subject to a margin of error, it was assessed that full implementation of the reforms could lower business costs in gross terms by a value approaching A $\$ 3.6$ billion (2010-11 Australian dollars). After account is taken of additional 
compliance costs to business the reforms together could raise gross domestic product (GDP) by around 0.4 per cent (or around $A \$ 6$ billion in 2010-11 Australian dollars). On the basis of implementation plans and possible adjustment lags, it was assessed that around 60 per cent of the total economy-wide effects would be felt by 2020 with some short-run national adjustment costs (Figure 7).

This study illustrates a workable approach to assessing and quantifying the impacts of economic reforms which differ in nature and economic footprint.

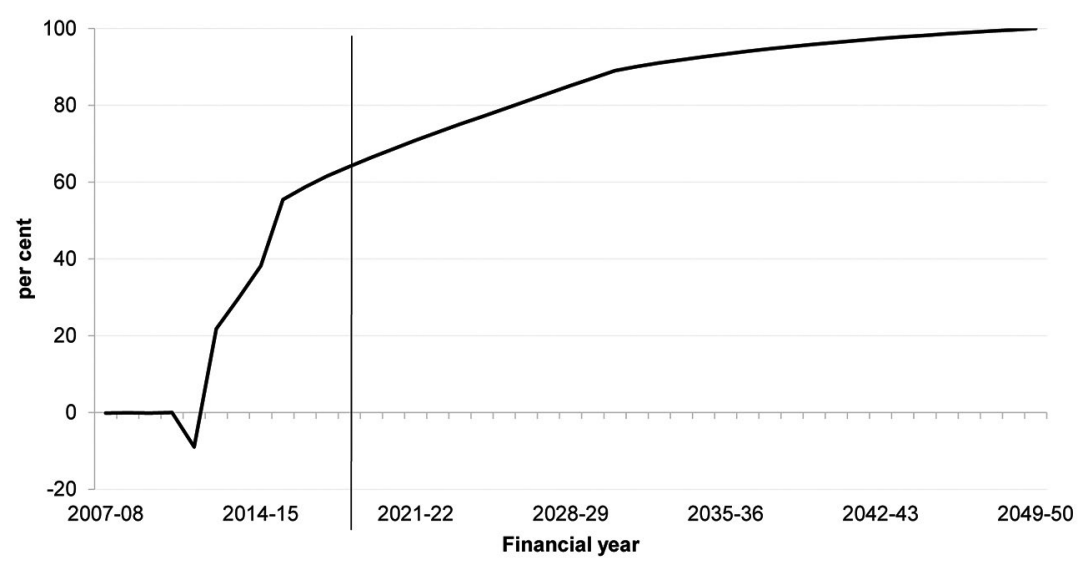

Per cent of projected increase in real GDP

Figure 7. Timescale over which the estimated longer-run impacts of selected regulatory reforms are estimated to occur, 2007-08 to 2049-50 Source: Productivity Commission 2012.

\section{Mutual recognition agreements}

Mutual recognition agreements provide means of fostering integration between like-minded economies. Typically, they are formed separately from bilateral and regional trade agreements. For example, in the 1990s, governments in Australia and New Zealand agreed that they would mutually recognise compliance with each other's laws for the sale of goods and the registration of occupations. 
The agreements adopt a negative list approach under which all goods and occupations are covered other than where exemptions are specified to restrict the coverage of the laws (such as to protect public health or safety) or to quarantine the coverage of the laws (such as on how goods are to be sold or in relation to sovereign rights).

The schemes are inherently decentralised, with administration and compliance largely delegated to individual regulators in each jurisdiction. There are also a number of central bodies-including an administrative appeals tribunal, a trans-Tasman occupations tribunal, ministerial councils and central government departments-that provide oversight and coordination roles, and a cross-jurisdictional review forum that enables jurisdictions to collectively oversee the schemes and coordinate actions.

Under the terms of the mutual recognition schemes, the agreements are required to be reviewed every five years, with reviews having occurred in 2003, 2009 and 2015 (Productivity Commission 2003, 2009 and 2015c, respectively). The latest review found that the schemes are well established as a means of making it easier to do business across borders. However, it was found that the value of the schemes risks being slowly eroded due to regulators not always implementing mutual recognition as required, weak oversight, and an increase in the number of goods and related laws permanently kept outside the scope of the schemes. There are also specific concerns being found with the operation of mutual recognition of occupations that have the potential to weaken the community's and regulators' trust in the schemes and undermine their legitimacy. Proximate influences identified include licensing in the least stringent jurisdiction in order to obtain registration through mutual recognition in a jurisdiction with more stringent regulation (termed shopping and hopping); continuing professional development requirements; background checking; and determinations of occupational equivalence. There is scope to improve governance arrangements and administration of the Australian and New Zealand system to enhance effectiveness and regulatory trustfulness.

An issue is to what extent can mutual recognition of goods and occupations under the Australia-New Zealand systems be meaningfully integrated with the EU system. A further issue is whether any integration could be extended according to a negative list approach or would it be more practicable to adopt a positive list approach? Importantly, would 
any move towards mutual recognition between systems generate a new set of administrative and origin requirements that could add to cost and erode in-principle advantages and cost effectiveness?

\section{Some areas of concern with preferential trade agreements}

\section{Intellectual property provisions}

The protection of intellectual property (IP) rights has become a mainstream feature of trade agreements at the bilateral, regional and multilateral level. While the WTO Trade-Related Aspects of Intellectual Property Rights (TRIPS) Agreement set (high) minimum standards for the scope, length of term, administration and enforcement of IP rights, some preferential agreements (including those to which Australia is a participant) have provided, or are seeking to provide, more stringent protections.

For individual countries, the impact of these provisions will depend directly on whether they are net exporters or importers of different forms of IP material. The ultimate impact of the provisions will depend on how they affect the level and growth in economic activity of national economies, partner economies and the broader global economy. For Australia, doubts have been raised about whether recent internationally negotiated IP provisions are likely to deliver benefits. In particular, the extension of the terms of patent protection from 16 to 20 years under TRIPS and the extension of copyright protection from the life of the author plus 50 years to plus 70 years under the Australia-United States trade agreement (AUSFTA) have been assessed as imposing net economic costs (Gruen, Bruce \& Prior 1996 and SCFTAAUSA 2004, respectively).

The relevance of trade-related IP issues for Australia has gained even greater prominence because of the potential for increased stringency in IP provisions in future agreements without commensurate economic benefits. The introduction of longer terms of IP protection (including patents, trademarks and copyright), lower hurdles for qualifying for IP rights, a greater role for government in enforcement and substantially increased penalty provisions, all could impose additional net costs on consumers and industry. To the extent that the return to IP holders awarded by more stringent IP laws outweighs the benefits to the broader economy, 
the provision would also impose net economic costs, lowering trading and growth potential across the bloc. If more stringent IP provisions negotiated in preferential agreements are projected into plurilateral and multilateral agreements, any costs could be even higher.

Given the capacity of IP systems to influence creative activity, trade and commerce and the complex legal and management systems established to manage IP law, the desirability of an overarching framework review of Australia's IP system was suggested (Productivity Commission 2013). The Australian Government's Competition Policy Review (Competition Policy Review 2015) later recommended that such a review be conducted by an independent body. Among other things, it recommended that the review cover the incorporation of IP provisions in international trade agreements.

The government then asked the Productivity Commission to undertake a public inquiry into Australia's intellectual property system. The Commission was asked to consider the current balance between access to ideas and products, and incentives to innovate and create, and to make recommendations to improve the wellbeing of the Australian community. In its final report, amongst other things, the Commission recognised that poorly designed IP rights can impose costs irrespective of whether a country is a net exporter or importer of IP (Productivity Commission 2016). This would occur when an IP system is weighted in favour of rights holders to the detriment of consumers and intermediate users. The Commission found that international agreements often contain prescriptive obligations that significantly constrain Australia's domestic policy arrangements. It suggested the need to improve the evidence base and analysis to inform international engagement, together with more transparent policy development.

An issue is to what extent can engagement between Australia and the EU with its diversity of member states, improve the evidence base and analysis of the impact of IP on the wellbeing of communities? A further issue is to what extent can such engagement provide leadership in the formulation of multilateral IP standards that better contribute to trade and commerce and improved community wellbeing? 


\section{Investor-state dispute settlement}

Some trade agreements and investment treaties entered into by the Australian Government contain provisions for settling disputes between an investor of one party to the agreement and the government of the other party - termed ISDS provisions. Under the provisions, dispute settlement options can include third-party arbitration. For example, the ISDS provisions in the bilateral investment treaty between Australia and Hong Kong were used by Philip Morris Asia to initiate third-party arbitration in relation to Australia’s tobacco plain packaging laws (Productivity Commission 2014, 2015a).

There has been a growing number of ISDS cases in recent years, rising to at least 70 new claims in 2015 from around 50 in the immediately preceding years (Figure 8). While claims have historically been initiated against developing and transitional states, recent years have witnessed an increase in the number of cases against more developed economies (around 40 per cent of the total for 2014 and 2015 were accounted for by claims on EU/OECD member states). A broad range of government measures have been challenged in recent years, including changes related to investment incentive schemes, concessional arrangements, cancellation or alleged breaches of contracts, revocation or denial of licenses and alleged direct or de facto expropriation (in part, the issue motivating Philip Morris Asia’s claim against the Australian Government).

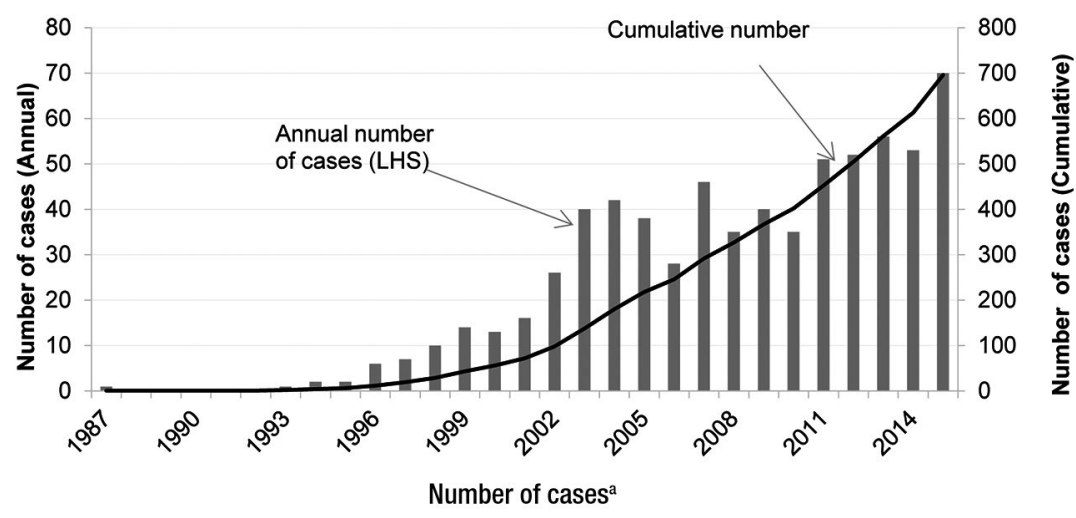

Figure 8. Known ISDS cases: 1987 to 2014

LHS, left-hand side; RHS, right-hand side. a) The total number of treaty-based investor-state disputes published on the UNCTAD Investment Policy Hub web page is 696 at April 2015. This estimate is adopted in the cumulative tally charted. The number of cases reported for 2014 and 2015 is based on a count of cases on the UNCTAD webpage at April 2015.

Source: UNCTAD 2016. 
While information on the amount of compensation sought by applicant investors is not available for all reported cases, the United Nations Conference on Trade and Development (UNCTAD) has reported claims ranging from less than US $\$ 1$ million (five cases) in 2015 to US $\$ 1$ billion or more ( 80 cases) in that year (UNCTAD 2016). Information on awards by tribunals is available for 112 cases. Of these, 27 were for US\$500 million or more. The largest group of awards totalled around US $\$ 50$ billion and related to a series of claims on the Russian Federation for actions by respondents against the Yukos Oil Company.

The inclusion of ISDS provisions in Australia's preferential trade agreements and investment treaties has become an increasingly contentious issue with concerns centering around the growth in the number of ISDS cases brought internationally; extension of substantive appeal rights available to foreigners but not available to domestic firms; risk of inhibiting regulatory change assessed to be in the communities' best interest (regulatory chill); effectiveness of safeguards and carve-outs; and lack of transparency and inadequate parliamentary scrutiny of ISDS (and other) provisions (SFADTLC 2014). There have also been concerns for the potential for the authority of domestic courts to be undermined by ISDS arbitration (French 2014).

Public consultations were organised by the European Commission in response to public debate about investment protection and ISDS in the proposed EU-USA trade agreement known as the Transatlantic Trade and Investment Partnership (TTIP). The consultations indicted that there was scope for improvement in agreement provisions including in relation to the protection of the right to regulate; the establishment and functioning of arbitral tribunals; the relationship between domestic judicial systems and ISDS; and the review of ISDS decisions through an appellate mechanism (European Commission 2015a). The European Commission subsequently proposed a new Investor Court System to replace existing ISDS provisions in trade negotiations including in the TTIP (European Commission 2015b). The proposal, amongst other things, includes an appellate body, precise definition of conditions under which investors can make a case and preservation of governments right to regulate.

In a parallel development, Germany, after indicating that it would not ratify the recently signed EU-Canada agreement (known as the Comprehensive Economic and Trade Agreement, CETA), which contains ISDS clauses, was reported to have subsequently withdrawn from that position (ICTSD 2014a , 2014b). A joint press announcement by European 
Commissioner for Trade and Canada's Minister of International Trade indicated that a legal review of the CETA text had been completed and that the investment chapter had been revised to 'strengthen the provisions on governments' right to regulate; move to a permanent, transparent and institutionalised dispute-settlement tribunal; revise the process for the selection of tribunal members, who will adjudicate investor claims; set out more detailed commitments on ethics for all tribunal members; and agree to an appeal system' (Freeland \& Malmstrom 2016). The intention to pursue a multilateral investment tribunal was also announced.

Australia has included ISDS clauses in six of its bilateral trade agreements: Singapore (2003), Thailand (2005), Chile (2009), ASEAN and New Zealand (2010), Korea (2014) and China (2015). Recent agreements include safeguards to protect the government's ability to regulate in the national interest. Australia also has ISDS provisions in its 21 traditional Investment Protection and Promotion Agreements (IPPAs) signed over the last three decades. ${ }^{2}$ An examination of foreign investment trends with Australia's main foreign investment partners suggests that ISDS provisions are unlikely to have been relevant considerations in the investment decisions of Australian firms investing abroad or foreign firms investing in Australia (Productivity Commission 2015a).

Given the persistent and unresolved debate surrounding foreign investment protection and ISDS and the emergence of substantive protections and appellate processes to address concerns, a relevant question to be considered is: 'What impact have existing ISDS provisions (or their absence) had on investment flows and do those impacts deem ISDS provisions worthwhile from a national perspective?' A further question is: 'Whether the evolution of ISDS provisions in recent trade agreements is likely to afford benefits in the national interest that warrant giving foreign corporations procedural rights (or investment guarantees) not available to resident investors?'

In its report on bilateral and regional trade agreements (Productivity Commission 2010b: 271), the Productivity Commission concluded there was an absence of an identifiable underlying economic problem on market failure grounds necessitating the inclusion of ISDS provisions in bilateral and regional trade agreements.

2 There are agreements are with Argentina, China, Czech Republic, Egypt, Hong Kong, Hungary, India, Indonesia, Laos, Lithuania, Mexico, Pakistan, Papua New Guinea, Peru, Philippines, Poland, Romania, Sri Lanka, Turkey, Uruguay and Vietnam. 


\section{Key messages from the Productivity Commission's 2010 study into trade agreements}

After considering the evidence received from business and government and quantitative modelling, the Productivity Commission in 2010 not surprisingly concluded that unilateral and MFN (that is nondiscriminatory) reforms are likely to offer the greatest benefits to Australia. This conclusion could reasonably be applied to other economies and federations of economies including the EU.

It also concluded that the likely economic benefits of preferential agreements are 'oversold', expectations are too high, and improvements are needed to the independence, transparency and timing of assessments of trade agreements, particularly when including issues that are traditionally domestic policy or that can add to costs.

The complexity of bilateral and regional trade agreements, the potential for provisions to impose net costs on the community and the availability of alternative reform options present a compelling case for analysis in advance of negotiations to answer the question, 'What are the most beneficial liberalisation measures available?', and of the agreement text at the conclusion of negotiations to answer the question, 'How well does the negotiated text compare to the benchmark?' Current processes, however, tend to be aspirational and fail to adequately assess the potential impacts and broader liberalisation alternatives. They also do not systematically quantify the costs and benefits against what otherwise may occur (the counterfactual), fail to consider the opportunity costs of pursuing preferential arrangements compared to non-discriminatory and other reform options, tend to ignore the extent to which agreements actually liberalise existing markets and are silent on the need for post-agreement evaluations of actual impacts. ${ }^{3}$

3 This is not to suggest that such analyses would be an easy undertaking. There are many practical difficulties involved in quantifying the impacts of agreements due to the variable quality and completeness of international services trade and investment statistics and the inherent difficulty in quantifying services and investment trade barriers compared to tariff measures. Nevertheless, given the potential for preferential agreements to impose net costs, these difficulties should not be used as a justification to avoid greater scrutiny, including through the quantification of potential impacts. 
Although there could be debate as to the most appropriate methodology for quantifying and assessing the scale and scope of the impacts of a bilateral or regional trade agreement, one point of reference is an economy-wide methodology for assessing the impacts and benefits of national economic reforms (Box 1). Such a methodology would identify the scope for change, the likely direct effects and economy-wide effects in a series of steps beginning with the identification of intended incremental changes and concluding with an overall assessment, including scope for improvement (Figure 9). The methodology could be applied in an ex ante analysis of the potential impacts of an agreement and in an expost analysis of an agreement text.

Under the methodology, ex ante evaluation would enable mutually beneficial unilateral reforms to be identified and considered as trade liberalisation alternatives. One of the most obvious options would be consideration of the removal of remaining customs tariffs on an MFN basis rather than the granting of tariff preferences supported by yet another regimen of rules of origin. Similarly, possible extensions to market access and the application of national treatment of service providers and investors could be considered on a non-preferential basis to maximise domestic benefits to negotiating partners and avoid the efficiency costs of trade diversion. The scope for and relative merits of appropriate mutual recognition arrangements could also be assessed as a means of overcoming impediments to trade and investment that cannot be overcome simply by negotiating market access.

A comprehensive ex post evaluation of a negotiated text would include a consideration of the likely incremental effects of an agreement over what would have occurred in its absence and alternatives, and an analysis of the prospective impacts of the negotiated text against the potential identified in the ex ante evaluation. It would cover the likely direct effects on trade and investment after taking account of all incremental changes, including how the take-up of any negotiated preferences would be influenced by rules of origin and other NTBs, carve-outs (sectors or activities where the agreement's commitments are quarantined) and negotiation and ongoing administration (and legal) costs. Economy-wide impacts to participating economies would be canvassed, taking account of the direct effects on barriers to trade and investment, and resource constraints in 
sectors gaining market access and the economy more broadly (such as labour market constraints). The prospect of inhibiting regulatory change (regulatory chill) through new treaty obligations would also be considered as would the contingent liabilities created by the agreement. Finally, the opportunity costs of the agreement in terms of delaying unilateral liberalisation for the sake of maintaining negotiating coin would be again evaluated.

\section{Box 1. Possible evaluation framework for trade agreements}

A comprehensive and rigorous analysis of an agreement would:

- provide information on the potential national economic impacts of the full agreement, including estimates of the economy-wide and distributional effects of change and the time paths over which benefits are likely to accrue and costs be incurred;

- assess, where practicable, the impact of the agreement to assist participating economies achieving their productivity and trade potential and the opportunities for improvement, considering remaining customs tariffs and other barriers to trade and investment, carve-outs and phasing, as well as the nature of merchandise trade, services trade, direct and portfolio investments, IP and the movement of natural persons between agreement partners and between the partners and other economies;

- assess the scope for the agreement to evolve over time to further assist participating economies achieving their productivity and trade potential, including through review provisions and built-in agendas; and

- assess the scope and appropriateness of the agreement to act as a model or template for other agreements to encourage effective, adaptable and accountable approaches to improve economic wellbeing.

At a more detailed level, the analysis would (for each chapter of the agreement):

- identify the current institutional settings and changes from those settings, including phasing arrangements;

- list the eligibility requirements (including rules of origin for goods, services and investment) for the receipt of preferences under the agreement;

- report on who or what could be potentially directly affected by the agreement, and levels and trends in bilateral trade and investment;

- identify the nature of potential direct benefits and costs of full implementation of the text of an agreement and impediments, if any, to the take-up of preferences;

- quantify, where practicable, the potential benefits and costs and the timescale over which they are likely to occur;

- identify and quantify, where practicable, transition costs compared to 'business as usual' that are likely to be incurred achieving preferences under the agreement;

- assess any potentially adverse impacts of an agreement, including inhibiting regulatory change (regulatory chill); and

- assess the opportunity cost of an agreement, including holding back domestic reform to maintain negotiating coin.

Sources: Based on Productivity Commission 2015: Box 4.5; Productivity Commission 2010a, 2010b. 


\section{Comprehensive evaluation}

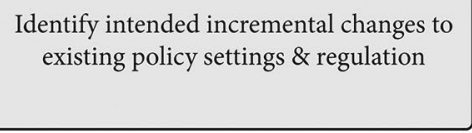

Identify scale of activities affected

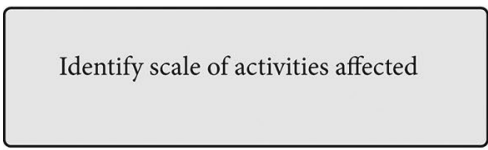

Estimate likely direct effects compliance \& administrative costs

Assess potential risks

Detail opportunity costs of delayed reform

Identify alternatives for reform

Provide overall assessment and scope for improvement

\section{Some potential evaluation indicators}

Requirements for new or revised legislation affecting bilateral trade \& investment \& movement of people

Trade \& investment \& local activity subject to provisions People affected

Import price changes

Take-up preferences

Productivity effects

Movement of people

Phasing arrangements

Trade negotiation costs RoO \& market access tests and costs

Quantitative modelling of trade, investment productivity \& population effects

Regulatory chill (arising from treaty obligations)

Contingent liabilities (such as from ISDS)

Quantify loss of benefits from foregoing unilateral tariff reductions \& services reform

Assess and compare gains from pursuing unilateral and multilateral alternatives

Measure of net benefit from agreement

Figure 9. Stages of a comprehensive evaluation and possible evaluation indicators

Source: Based on Productivity Commission 2015: Figure 4.3. 


\section{Bringing the EU and Australia closer together}

Bringing the EU and Australia closer together is naturally supported by similarly high regulatory standards and stages of economic development. There is also a similar intent of academic and trade qualifications and ways of working despite geographic separation. These common elements naturally bring the economies of the EU and Australia closer together. But there are impediments, including traditional trade barriers; protectionist sentiment in professional bodies and ways of working; local regulatory requirements relating to service provision; technology moving ahead of regulations-just think what can be done with information and communications technology compared to a decade ago; and geographic and time zone differences, which still matter. There are also differences in language and cultural norms. There are workarounds for business (such as foreign direct investment, movement of natural persons and business partnerships), but these may not be optimal, warranting attention to the barriers to trade and investment. (The workarounds also do not cover the need for governments to cooperate on matters of taxation and other protocols.)

So, what might be brought up internationally that will lead to worthwhile domestic reform and provide a bridge to bring Australia and the EU closer? On the merchandise trade side, remaining tariffs and rules of origin seem obvious candidates. Other candidates may be identified around product standards, packaging and labelling and the movement of merchandise through border security. And, while it is often said that tariffs are low and have little protective value, if this is the case, 'why are governments persisting with tariff regimes?' And, more puzzling, with low tariffs, 'why the insistence on complex rules of origin in bilateral and regional agreements?'

On the services side, mutual recognition of qualifications and affiliations would seem to be a strong candidate for early attention. But this raises the potentially sensitive question of how to allow for differences in professional, regulatory and other standards, and allow for criminal and other checking. The pacing of regulation with technology, which gives recognition to the reality of the latest advances, is another matter that would seem to require ongoing vigilance, and that would lend itself to 
close cooperation between like-minded economies. Questions in this regard include 'Is enough already being done and what more could reasonably be done to deliver community-wide benefits?'

But, in all these developments, in bringing Australia and the EU closer, can there be compelling reasons to sidestep the MFN and national treatment principles? In conclusion, one final question: 'What would it take to make EU-Australian cooperation truly trendsetting in the application of these principles and to compensate for lack of progress in Doha?'

\section{References}

APEC (Asia Pacific Economic Cooperation) (2009), 'APEC elements for simplifying customs documents and procedures relating to rules of origin', Appendix 3, in Committee on Trade and Investment, Annual Report to Ministers (APEC: Singapore).

Competition Policy Review (2015), Competition Policy Review Final Report (Professor Ian Harper, Chairman) (Commonwealth of Australia: Canberra).

European Commisson (2015a), Online Public Consultation on Investment Protection and Investor-to-State Dispute Settlement (ISDS) in the Transatlantic Trade and Investment Partnership Agreement (TTIP), Commission Staff Working Document, SWD(2015) 3 Final (European Commission: Brussels), January.

European Commisson (2015b), 'Commission proposes new Investment Court System for TTIP and other EU trade and investment negotiations', Press release, Brussels, September.

Fink, Carsten \& Deunden Nikomborirak (2007), Rules of Origin in Services: A Case Study of Five ASEAN Countries, Policy Research Paper No. 4130 (World Bank: Washington, DC), February.

Freeland, Chrystia \& Cecilia Malmström (2016), 'Joint Statement by European Commissioner for Trade and Canada's Minister of International Trade on Canada-EU trade agreement', 29 February.

French, Robert (2014), 'Trade Law and the Australia Courts', Speech to Law Council of Australia, International Trade Law Symposium, 18 September, National Portrait Gallery, Canberra. 
Gretton, Paul (2013), 'National economic reform in a federal system: The case study of Australian National Competition Policy and related reforms', in Stephen Howes and M. Govinda Rao (eds), Federal Reform Strategies, Lessons from Australia and Asia (Oxford University Press: New Delhi). doi.org/10.1093/acprof:oso/9780198092001.003.0002.

Gruen, Nicholas, Bruce, Ian \& Prior, Gerard (1996), Extending Patent Life: Is It in Australia's Economic Interest?, Staff Information Paper (Industry Commission: Canberra).

ICTSD (International Centre for Trade and Sustainable Development) (2014a), 'Germany Changes Tack on ISDS in EUCanada Trade Deal', Media release, 4 December. Available at www.ictsd.org/bridges-news/bridges/news/germany-changes-tack-onisds-in-eu-canada-trade-deal, last accessed 25 April 2016.

ICTSD (2014b), 'EU, Canada sign trade deal as Germany raises ISDS questions', Media release, 2 October. Available at www.ictsd.org/ bridges-news/biores/news/eu-canada-sign-trade-deal-as-germanyraises-isds-questions, last accessed 25 April 2016.

Johnson, Robert C. (2014), 'Five facts about value-added exports and implications for macroeconomics and trade research', Journal of Economic Perspectives 28(2): 119-42. doi.org/10.1257/jep.28.2.119.

Johnson, Robert C. \& Noguera, Guillermo (2012), Fragmentation and Trade in Value Added over Four Decades, NBER Working Paper No. 18186 (National Bureau of Economic Research: Cambridge).

Manchin, Miriam \& Annette O. Pelkmans-Balaoing (2007), Rules of Origin and the Web of East Asian Free Trade Agreements, Policy Research Working Paper No. 4273 (World Bank: Washington, DC), July.

Productivity Commission (2002), Offshore Investment by Australian Firms: Survey Evidence, Commission Research Paper (AusInfo: Canberra).

Productivity Commission (2003), Evaluation of the Mutual Recognition Schemes, Research Report (Productivity Commission: Canberra). 
Productivity Commission (2004a), 'Industry assistance in Australia and New Zealand under the CER Agreement', Supplement to Productivity Commission Research Report, Rules of Origin under the AustraliaNew Zealand Closer Economic Relations Trade Agreement (Productivity Commission: Canberra), June.

Productivity Commission (2004b), Rules of Origin under the AustraliaNew Zealand Closer Economic Relations Trade Agreement, Research Report (Productivity Commission: Canberra).

Productivity Commission (2005), Review of National Competition Policy, Inquiry Report No. 33 (Productivity Commission: Canberra).

Productivity Commission (2006), Potential Benefits of the National Reform Agenda, Research Report (Productivity Commission: Canberra).

Productivity Commission (2009), Review of Mutual Recognition Schemes, Research Report (Productivity Commission: Canberra).

Productivity Commission (2010a), Bilateral and Regional Trade Agreements, Research Report (Productivity Commission: Canberra).

Productivity Commission (2010b), Impacts and Benefits of COAG Reforms: Reporting Framework, Research Report (Productivity Commission: Canberra).

Productivity Commission (2012), Impacts of COAG Reforms: Business Regulation and VET, Research Report (Productivity Commission: Canberra).

Productivity Commission (2013), Trade \& Assistance Review 2011-12, Annual Report Series (Productivity Commission: Canberra).

Productivity Commission (2014), Trade \& Assistance Review 2012-13, Annual Report Series (Productivity Commission: Canberra).

Productivity Commission (2015a), Trade \& Assistance Review 2013-14, Annual Report Series (Productivity Commission: Canberra).

Productivity Commission (2015b), Trade \& Assistance Review 2013-14, Methodological Annex (Productivity Commission: Melbourne).

Productivity Commission (2015c), Mutual Recognition Schemes, Research Report (Productivity Commission: Melbourne). 
Productivity Commission (2016), Intellectual Property Arrangements, Final Report (Productivity Commission: Canberra).

SCFTAAUSA (Select Committee on the Free Trade Agreement between Australia and the United States of America) (2004), Final Report, August.

SFADTLC (Senate Foreign Affairs, Defence and Trade Legislation Committee) (2014), Trade and Foreign Investment (Protecting the Public Interest) Bill 2014, Final Report (Commonwealth of Australia: Canberra), August.

UNCTAD(UnitedNations Conferenceon TradeandDevelopment) (2016), 'Investment Policy Hub, Investment Disputes Navigator'. Available at investmentpolicyhub.unctad.org/ISDS?status=1000, last accessed 20 April 2016.

World Bank (2016a), 'Topical Issue, Potential Macroeconomic Implications of the Trans-Pacific Partnership', in Global Economic Prospects, January 2016: Spillovers amid Weak Growth (World Bank: Washington, DC), 219-36.

World Bank (2016b), 'World Development Indicators: Table 6.6, Tariff Barriers'. Available at wdi.worldbank.org/table/6.6, last accessed 17 May 2016. 
This text is taken from Australia, the European Union and the New Trade Agenda, edited by Annmarie Elijah, Don Kenyon, Karen Hussey and Pierre van der Eng, published 2017 by ANU Press, The Australian National University, Canberra, Australia. 